\title{
Challenging Multi-Morbidities: Obstructive Sleep Apnoea and Cancer
}

Isaac Almendros, $\mathrm{PhD}^{1,2,4}$, Josep María Montserrat, MD, PhD $2,3,4$ and Ramon Farré, $\mathrm{PhD}^{1,2,4}$

${ }^{1}$ Department of Biophysics and Bioengineering, Faculty of Medicine, University of Barcelona, Barcelona, Spain; ${ }^{2}$ Centre for Biomedical Research

in the Respiratory Diseases Network (CIBERES), Madrid, Spain; 'Sleep Laboratory, Department of Pulmonology, Hospital Clinic, University of Barcelona,

and ${ }^{4}$ Institute for Biomedical Research August Pi i Sunyer, Barcelona, Spain

\section{ABSTRACT}

Obstructive sleep apnoea (OSA) is a highly prevalent disorder in adults and has been associated with a large array of end-organ morbidities affecting multiple organ systems. From recent epidemiological studies there is growing evidence linking this sleep breathing disorder with an increased incidence and enhanced mortality in cancer, where the recurrent oxygen desaturations experienced by patients with OSA have been proposed as a major determinant of adverse cancer outcomes. The use of translational models mimicking the intermittent hypoxia and sleep fragmentation that characterize OSA have shown that both challenges can enhance tumour growth and malignancy in several types of cancers including melanoma, kidney cancer, and lung carcinoma. Moreover, translational and basic researches have provided solid emerging evidence implicating the immune system in the adverse cancer outcomes linked to intermittent hypoxia. Here we review all data available to date on the relationship between OSA and cancer from clinical and translational studies. (BRN Rev. 2016;2:170-84)

Corresponding author: Isaac Almendros, isaac.almendros@ub.edu

Key words: Cancer. Inflammation. Intermittent hypoxia. Obstructive sleep apnoea. Sleep fragmentation. 


\section{OBSTRUCTIVE SLEEP APNOEA}

Obstructive sleep apnoea (OSA) is a highly prevalent sleep disorder, which, depending on sex and age, can affect between 4 and 10\% of the adult population ${ }^{1}$ and is characterized by repetitive occlusions of the upper airway during sleep. These repetitive obstructions can lead to recurrent blood oxygen desaturations and sleep fragmentation. As presented in this review, very recent data from epidemiological, clinical, and translational studies have suggested that there is a potential link between OSA and cancer.

\section{EVIDENCES FROM EPIDEMIOLOGICAL AND CLINICAL DATA}

\section{Population and Community Based Studies on Obstructive Sleep Apnoea and Cancer}

Although there is growing evidence on the possible association between OSA and cancer, the number of studies based on human data is still scarce and present some limitations. For instance, most of the epidemiological and clinical studies are not focused on specific types of cancers. Moreover, other potential cancer risks and/or protective factors are not well controlled because the historical focus of the cohorts was based on respiratory disorders instead of cancer. However, and in spite of these limitations, the majority of these studies show increased cancer incidence, mortality, and aggressiveness in moderate-to-severe OSA patients.

The first population-based study linking both entities was carried out by the Wisconsin cohort, which included 1,522 subjects with a 22-year follow-up. Nieto et al. ${ }^{2}$ found an association between the apnoea-hypopnoea index (AHI), the most commonly employed metrics to measure the severity of OSA, with cancer mortality. In particular, after adjusting for well-known confounding factors such as age, sex, body mass index, and smoking habits, OSA presented increased rates of cancer mortality in a dose-response fashion. The adjusted relative hazards of cancer mortality in comparison to non-OSA subjects were 1.1 (95\% confidence interval (CI): 0.5-2.7), 2.0 (95\% CI: 0.7-5.5), and 4.8 (95\% CI: 1.7-13.2) for mild, moderate, and severe OSA patients, respectively. Subsequent analyses from this cohort showed that this association appears stronger when, instead of AHI, oximetry indices were used to characterize OSA severity. From stratified analyses, Nieto et al. found clearer case-control differences among the non-obese OSA patients, evidencing that obesity is an important confounding factor in OSA. Taking into account these findings, it is plausible that, as discussed below, OSA potentiates cancer incidence and mortality through the well-documented metabolic consequences of this sleep breathing disorder.

Similar results on a potential OSA-cancer relationship were found by the Busselton cohort. In that work, Marshall et al. ${ }^{3}$ presented a 20-year follow-up of 397 OSA patients. After data adjustment, the authors found that moderate-to-severe OSA was significantly associated with cancer incidence and mortality, presenting a hazard ratio (HR) of $2.5(95 \% \mathrm{CI}$ : 1.2-5.0) and 3.4 (96\% CI: 1.1-10.2), respectively, in comparison to non-OSA subjects.

Two studies only based on questionnaires did not find a clear interaction between OSA 
and cancer incidence. In one of them, all the participants answered questions about snoring and breathing cessations $(n=8,783)$ and only in a subset of participants was daytime sleepiness also included $(n=5,894)^{4}$. Although no overall association between symptoms of sleep disordered breathing and incident cancer was observed, in a small group of subjects with high daytime sleepiness, the authors observed a markedly higher cancer incidence (HR: 4.09; 95\% CI: 1.58-10.55) in participants under 50 years old ${ }^{4}$. Christensen et al. also found a higher risk of virus/immune-related cancers (HR: 2.73; 95\% CI; 1.27-5.91) and alcohol-related cancers (HR: 4.92; 95\% CI: 1.45-16.76) among participants with daytime sleepiness. In addition, the sleep disordered breathing symptoms were associated with a higher risk of smoking-related cancers. In the other study based on questionnaires asking about snoring and sleeping time of participants, Cohen et al. ${ }^{5}$ did not find any relationship between melanoma incidence and snoring. However, these studies have an important limitation since the participants did not undergo any objective and standard sleep tests to confirm the presence of OSA.

There are two more Taiwanese series studies analysing data provided from their National Health Institute. In the first series, the cohort consisted of women diagnosed with OSA $(n=846)$ with a follow up of five years ${ }^{6}$. The authors observed that OSA patients had a greater risk of developing a breast cancer (HR: 2.09; 95\% CI: 1.06-4.12) compared to control subjects ${ }^{6}$. In contrast to the previous studies including all types of cancer, the risk of breast cancer seems to be higher in older women. In particular, the HR was 2.06 (95\% CI: $0.90-4.70)$ in women aged 30-59 years and
3.05 (95\% CI: 0.9010.32) in those over 60 years old as compared with those aged between $0-29$ years. This is a relevant finding considering the potential metabolic disorders associated to menopause in women. The other Taiwanese study included 23,055 OSA patients matched by age and sex to subjects without $\mathrm{OSA}^{7}$. The authors evaluated the incidence of primary malignant central nervous system (CNS) cancers over a 10-year period and found that the incidence density $(10,000$ individual/year) was 2.14 and 1.28 in OSA patients and non-OSA subjects, respectively. The risk of incidence in CNS cancers presented an HR of 1.54 (95\% CI: 1.01-2.37) after adjusting for some common confounding variables such as age, sex, and obesity.

Very recently, Fang et al. ${ }^{8}$ published a case-control study by searching the outpatient and inpatient claims databases with any cancer from the Taiwan National Health Insurance program. The study included 68,422 patients; each one was matched with two controls. After adjustment for several confounders, OSA significantly increased the risks of breast cancer (HR: 2.10; 95\% CI: 1.16-3.80), nasal cancer (HR: 5.96; 95\% CI: 2.96-11.99), prostate cancer (HR: 3.69; 95\% CI: 1.98-6.89), and bladder cancer (HR: 2.91; 95\% CI: 1.30-6.50).

\section{Clinical Studies on Obstructive Sleep Apnoea and Cancer}

The first clinical study appeared in 2013 from the Spanish Sleep Group. This work was a retrospective and multicenter study with a follow-up of 4.5 years and composed of 4,910 OSA patients not previously diagnosed with cancer ${ }^{9}$. Campos-Rodríguez et al. 
showed a clear association between the severity of OSA and the incidence of all types of cancer. The AHI and the percentage of sleep time presenting values of oxygen saturation $<90 \%$, or TSat $(90)$, were categorized by tertiles and used as surrogates of OSA severity. Compared with the lowest TSat(90) category $(<1.2 \%)$, the adjusted hazards of cancer incidence for increasing categories were 1.58 for TSat $(90)$ between 1.2 and $12 \%$, and 2.33 for TSat $(90)>12 \%$. The AHI was not associated with cancer incidence in the adjusted analyses, except for patients younger than 65 years. In a subsequent study on the same group of OSA patients, MartínezGarcía et al. ${ }^{10}$ investigated cancer mortality and found a pattern similar to that observed in cancer incidence 9 . Specifically, log-transformed TSat(90) was independently associated with increased cancer mortality. Also, according to previous findings, the strongest association was found in those patients less than 65 years old. Interestingly, a posterior sub-analysis including only patients previously diagnosed with cancer found that TSat(90) was an independent predictor of cancer prognosis.

The increased cancer incidence observed in OSA patients from the Australian, Taiwanese, and Spanish works was not reproduced in a study from the Ontario health administrative databases. In that work, Kendzerska et al. ${ }^{11}$ included 10,149 patients who underwent a sleep study and $5 \%$ of them had a cancer diagnosis at baseline. After a follow-up of 7.8 years, $6.5 \%$ of those OSA patients free of cancer suffered incident cancer. After adjustment for age, sex, body mass index, and smoking status at baseline, the authors did not find an association with either prevalence or incidence of cancer. However, in a subgroup of patients they found that oxygen desaturation, but not AHI, was significantly associated with smoking-related cancers.

More recently, the first study based on a specific type of cancer and OSA has been published. Martínez-García et al. ${ }^{12}$ analysed the potential relationship between OSA with $\mathrm{cu}-$ taneous malignant melanoma (CMM) aggressiveness. This was a multicenter observational study that included 56 patients diagnosed with CMM. All patients underwent a complete sleep study, and tumour mitotic rate, Breslow index, presence of ulceration, stage of disease, and growth rate of melanoma were assessed as markers of CMM aggressiveness. The prevalence of OSA was higher in patients diagnosed with CMM. In particular, $60.7 \%$ of them presented an AHI $\geq 5$ events/ hour and $14.3 \%$ had severe OSA (AHI $\geq 30$ ). In fully adjusted multivariate analyses, AHI and oxygen desaturation indices were independently associated with an increased skin depth and growth rate of melanoma.

The last reported preliminary data aimed at assessing the association between OSA and clinical markers is focused on kidney tumour progression measured by Fuhrman grade and tumour size in patients with renal carcinoma ${ }^{13}$. The retrospective study included 2,579 patients who underwent radical or partial nephrectomy for renal carcinoma. OSA was not found to be associated with tumour size. However, more patients with OSA had high Fuhrman grade compared to those without OSA (51 vs. $38 \%$; $13 \%$ risk difference; $95 \%$ CI: 5-20\%). On multivariable analysis, the association remained significant (odd ratio: (OR): 1.41; 95\% CI: 1.00-1.99). 
Taking into account the entire patient studies already available to date, it seems that the association between OSA and cancer mortality is more consistent and clearer than in cancer incidence. This fact could be explained by other potential risk factors such as genetic background, obesity, and the presence of carcinogenic environmental factors, which can play a crucial role in tumourigenesis (Table 1).

\section{Role of Immune System Changes Linking Obstructive Sleep Apnoea and Cancer}

There are two very recent clinical studies suggesting potential mechanisms that could partially explain the increased incidence of cancer in OSA patients. Both works, although with different aims, suggest that the immune changes induced by OSA could facilitate malignant cells to leave the tumour and thus metastasize. In a first work, Gharib et al. ${ }^{14}$ investigated the transcriptome of peripheral blood leukocytes (PBL) in response to continuous positive airway pressure (CPAP), which constitutes the first line of treatment for OSA. In order to explore the molecular pathways affected by CPAP, authors quantified the whole genome expression of PBLs by microarray analysis from severe OSA patients before and after treatment. As expected, CPAP treatment improved most of the sleep variables measured in OSA patients. Interestingly, and unexpected by the authors, the gene set enrichment analysis from PBLs revealed a number of enriched gene sets and many neoplasm-related pathways that were downregulated after CPAP treatment. Further network analyses identified several densely connected genes, which are already known as key modulators of cancer progression.

In a second work, Gaoatswe et al. ${ }^{15}$ investigated whether invariant natural killer $\mathrm{T}$ (iNKT) cells could be reduced in OSA patients. The iNKT cells are prominently activated when foreign lipids are present and play an important role in cancer immunity. In fact, a reduction in iNKT cell numbers in the peripheral blood has been correlated with several autoimmune or inflammatory conditions and cancers ${ }^{16}$. The authors showed that patients with severe OSA presented considerably fewer iNKT cells $(0.18 \%)$ compared to patients with moderate $(0.24 \%)$ or no OSA $(0.35 \%)$. In fact, the authors found that the amount of iNKT cells correlated negatively with AHI $(r=-0.58 ; \mathrm{p}=0.001)$, oxygen desaturation index $(\mathrm{r}=-0.58 ; \mathrm{p}=0.0003)$, and TSat(90) $(\mathrm{r}=-0.5407 ; \mathrm{p}=0.005)$. Interestingly, changes in these immune system cells were reverted after 12 months of nasal CPAP therapy. Moreover, application of hypoxia to these cells in culture resulted in increased apoptosis and impaired cytotoxicity, supporting the notion that OSA-induced iNKT cell alterations could facilitate tumourigenesis and tumour progression.

\section{Circadian Rhythm Alterations and Poor Sleep Quality as Risk Factors of Cancer}

Although not directly focused on OSA, several epidemiological studies related to sleep duration and cancer outcomes have started to emerge recently ${ }^{17-30}$. The disruption of the circadian rhythm could augment the risk of several types of cancer ${ }^{31-33}$. Nightshift work and 
TABLE 1. Summary of the available epidemiological and clinical studies on the association between obstructive sleep apnoea and cancer incidence (green) and mortality/aggressiveness (red)

\begin{tabular}{|c|c|c|c|c|c|c|}
\hline References & Subjects & Study design & Diagnosis & Outcome & $\begin{array}{l}\text { Association } \\
\text { OSA-cancer }\end{array}$ & Main findings \\
\hline $\begin{array}{l}\text { Nieto et al. }{ }^{2} \\
2012\end{array}$ & 1,522 & $\begin{array}{l}\text { Population-based } \\
\text { study (22-year } \\
\text { follow-up) }\end{array}$ & PSG or RP & Cancer mortality & Yes & $\begin{array}{l}\text { SDB was associated with cancer } \\
\text { mortality, especially with TSat(90). } \\
\text { The relationship was stronger in } \\
\text { non-obese population and } \\
\text { non-treated patients with CPAP }\end{array}$ \\
\hline $\begin{array}{l}\text { Christensen et } \\
\text { al. }{ }^{4} 2013\end{array}$ & 8,783 & $\begin{array}{l}\text { Prospective } \\
\text { cohort study } \\
\text { (13-year } \\
\text { follow-up) }\end{array}$ & $\begin{array}{l}\text { Questions } \\
\text { about OSA } \\
\text { symptoms }\end{array}$ & $\begin{array}{l}\text { Cancer } \\
\text { incidence }\end{array}$ & $\begin{array}{l}\text { Limited to } \\
\text { cancer type }\end{array}$ & $\begin{array}{l}\text { No relationship between OSA } \\
\text { symptoms with cancer incidence } \\
\text { except for patients younger than } 50 \\
\text { years with smoking-related cancers }\end{array}$ \\
\hline $\begin{array}{l}\text { Campos-Rodri- } \\
\text { guez et al. }{ }^{9} \\
2013\end{array}$ & 4,910 & $\begin{array}{l}\text { Multicenter } \\
\text { retrospective } \\
\text { clinical cohort } \\
\text { study (4.5-year } \\
\text { follow-up) }\end{array}$ & Full PSG & $\begin{array}{l}\text { Cancer } \\
\text { incidence }\end{array}$ & Yes & $\begin{array}{l}\text { Severe OSA presented increased } \\
\text { incidence of cancer in patients } \\
\text { under } 65 \text { year old }\end{array}$ \\
\hline $\begin{array}{l}\text { Marshall et al. }{ }^{3} \\
2014\end{array}$ & 397 & $\begin{array}{l}\text { Population-based } \\
\text { study (20-year } \\
\text { follow-up) }\end{array}$ & $\begin{array}{l}\text { Respiratory } \\
\text { disturbance } \\
\text { index }\end{array}$ & $\begin{array}{l}\text { Cancer } \\
\text { incidence and } \\
\text { mortality }\end{array}$ & Yes & $\begin{array}{l}\text { OSA was associated with cancer } \\
\text { mortality and cancer incidence }\end{array}$ \\
\hline Chen et al. ${ }^{7} 2014$ & $\begin{array}{l}23,055 \text { OSA } \\
\text { and } \\
69,165 \\
\text { controls }\end{array}$ & $\begin{array}{l}\text { Population- } \\
\text {-based-study } \\
\text { (10-year } \\
\text { follow-up) }\end{array}$ & Full PSG & $\begin{array}{l}\text { Central nervous } \\
\text { system cancer } \\
\text { incidence }\end{array}$ & $\begin{array}{l}\text { Limited to } \\
\text { cancer type }\end{array}$ & $\begin{array}{l}\text { Higher central nervous system } \\
\text { cancer incidence (especially brain } \\
\text { cancer) in OSA patients in } \\
\text { comparison with control group } \\
\text { without OSA }\end{array}$ \\
\hline $\begin{array}{l}\text { Chang et al. }{ }^{6} \\
2014\end{array}$ & $\begin{array}{l}846 \text { women } \\
\text { with OSA } \\
\text { and } 4,230 \\
\text { controls }\end{array}$ & $\begin{array}{l}\text { Population- } \\
\text {-based-study } \\
\text { (5-year } \\
\text { follow-up) }\end{array}$ & Full PSG & $\begin{array}{l}\text { Breast cancer } \\
\text { incidence }\end{array}$ & $\begin{array}{l}\text { Limited to } \\
\text { cancer type }\end{array}$ & $\begin{array}{l}\text { Higher breast cancer incidence in } \\
\text { OSA with respect to healthy women }\end{array}$ \\
\hline $\begin{array}{l}\text { Martínez-García } \\
\text { et al. }{ }^{10} 2014\end{array}$ & 5,427 & $\begin{array}{l}\text { Multicenter } \\
\text { retrospective } \\
\text { clinical cohort } \\
\text { study (4.5-year } \\
\text { follow-up) }\end{array}$ & $\begin{array}{l}\text { Full PSG or } \\
\text { RP }\end{array}$ & Cancer mortality & Yes & $\begin{array}{l}\text { OSA variables TSat }(90) \text { and } \mathrm{AHI} \text { were } \\
\text { associated with higher cancer } \\
\text { mortality, stronger in male patients } \\
\text { under } 65 \text { years }\end{array}$ \\
\hline $\begin{array}{l}\text { Martínez-García } \\
\text { et al. }{ }^{12} 2014\end{array}$ & $\begin{array}{l}56 \text { with } \\
\text { melano- } \\
\text { ma }\end{array}$ & Multicenter & $\mathrm{RP}$ & $\begin{array}{l}\text { Melanoma } \\
\text { aggressive- } \\
\text { ness }\end{array}$ & Yes & $\begin{array}{l}\text { High prevalence of OSA in patients } \\
\text { diagnosed with melanoma; OSA } \\
\text { associated with melanoma } \\
\text { malignancy }\end{array}$ \\
\hline $\begin{array}{l}\text { Kendzerska et } \\
\text { al. }{ }^{11} 2014\end{array}$ & 10,149 & $\begin{array}{l}\text { Multicenter } \\
\text { retrospective } \\
\text { clinical cohort } \\
\text { study (7.8 } \\
\text { year-follow-up) }\end{array}$ & Full PSG & $\begin{array}{l}\text { Cancer } \\
\text { incidence }\end{array}$ & $\begin{array}{l}\text { Limited to } \\
\text { cancer type }\end{array}$ & $\begin{array}{l}\text { Non-significant relationship between } \\
\text { OSA and incident of cancer after } \\
\text { adjusting variables. Smoking-related } \\
\text { cancer was associated with } \\
\text { TSat(90) }\end{array}$ \\
\hline $\begin{array}{l}\text { Cohen et al. }{ }^{5} \\
2015\end{array}$ & $2,301,445$ & $\begin{array}{l}\text { Prospective } \\
\text { cohort study } \\
\text { (from 2008) }\end{array}$ & $\begin{array}{l}\text { Self-reported } \\
\text { snoring and } \\
\text { sleeping } \\
\text { time }\end{array}$ & $\begin{array}{l}\text { Cancer } \\
\text { incidence }\end{array}$ & No & $\begin{array}{l}\text { No relationship between SDB } \\
\text { (evaluated as snoring) and cancer } \\
\text { incidence was observed }\end{array}$ \\
\hline Fang et al. ${ }^{8} 2015$ & $\begin{array}{l}68,422 \text { OSA } \\
\text { and } \\
136,844 \\
\text { controls }\end{array}$ & $\begin{array}{l}\text { Prospective } \\
\text { cohort study } \\
\text { (10-year } \\
\text { follow-up) }\end{array}$ & Full PSG & $\begin{array}{l}\text { Cancer } \\
\text { incidence }\end{array}$ & Yes & $\begin{array}{l}\text { OSA was associated to increased } \\
\text { incidence of nasal, breast, prostate } \\
\text { and bladder cancer }\end{array}$ \\
\hline
\end{tabular}

AHI: apnoea-hypopnoea index; CPAP: continuous positive airway pressure; OSA: obstructive sleep apnoea; PSG: polysomnography; RP: respiratory polygraphy; SDB: sleep-disordered breathing; TSat(90): oxygen saturation $<90 \%$. 
the use of social technologies during the night are the most representative forms of circadian rhythm alteration in modern society. Shift work has been widely associated with an increased prevalence of breast, prostate, and colorectal cancers ${ }^{31-34}$.

Schernhammer et al..$^{35}$ prospectively studied the relationship between rotating nightshift work and breast cancer. Among 115,022 women without cancer at baseline, 1,352 finally developed breast cancer during the following 12 years. In this study, only those women who reported more than 20 years of exposure to rotating nightshift work increased their relative risk of breast cancer (RR: 1.79; 95\% CI: 1.06-3.01). Very similar results were found recently by Åkerstedt et al. ${ }^{36}$ from a Swedish prospective cohort study where twins born were included. Data on cancer were obtained from the Swedish Cancer Registry and from the Cause of Death Register, and linked to the twins by using the unique person identification number available for all Swedish citizens. The results obtained in this study showed an association between long exposure to night work ( $>20$ years) with breast cancer in women. Similarly, Viswanathan et al. ${ }^{37}$ prospectively studied a cohort of 121,701 women; 53,487 of them reported rotating nightshift work in 1988 and were followed during the following 16 years. Invasive endometrial cancer was diagnosed in 515 women. The authors reported that women exposed to nightshift work during at least 20 years had a significantly increased risk of endometrial cancer (RR: 1.47; 95\% CI: 1.03-1.14). In further stratified analyses, the authors found that the coexistence of obesity with shift work markedly enhanced their baseline risk of endometrial cancer (multivariate RR: 2.09; 95\%
CI: 1.24-3.52) compared with obese women not working at night. Hansen et al. ${ }^{38}$ compared 7,035 women aged 30-54 years with primary breast cancer retrieved from the Danish Cancer Registry. Female controls, free of cancer at the time of diagnosis, were matched individually considering age. After accounting for reproductive history and socioeconomic status, they found a 1.5 -fold increase in the risk (95\% CI: 1.2-1.7) of primary breast cancer in women who had been employed for at least six months with predominantly night work $(>60 \%)$. Schernhammer et al. ${ }^{34}$, in a prospective study, explored the potential association between working rotating nightshifts and the risk of colorectal cancers among female participants. From 78,586 women followed up for 10 years, the authors reported that long-term shift work ( $>15$ years) promoted an increased risk of colorectal cancer of 1.35 (95\% CI: 1.03-1.77) compared with women without experience of rotating night shifts of 1.00 (95\% CI: 0.84-1.19).

\section{EVIDENCES FROM TRANSLATIONAL MODELS AND POTENTIAL MECHANISMS}

\section{Hypoxia and Tumour Malignancy}

Hypoxia is one of the most common conditions encountered within the tumour microenvironment, and has been related to an enhanced metastatic potential, resistance to chemo- and radiotherapy, and poor prognosis ${ }^{39-42}$. In fact, the strong association between the development of metastasis and the proportion of hypoxic cells in primary tumours suggests that hypoxia can drive tumour cells to a more aggressive and metastatic phenotype. It has 
been postulated that hypoxia can itself upregulate a wide array of genes associated with tumour progression and metastasis through the transcriptional activity of hypoxia-inducible factors (HIF-1, HIF-2) ${ }^{43,44}$. Currently, clinically tested systemic therapeutic strategies are employed to directly target hypoxic tumour cells to control the growth and progression of primary tumours.

Another characteristic of solid tumours is their heterogeneous distribution of blood flow, with significant hypoxia in low-flow regions. When malignant cells are distant to blood vessels, there is an imbalance between oxygen delivery and consumption, leading to a hypoxic and acidic cell microenvironment. However, in the periphery, i.e. in areas where the tumour is advancing, the newly formed vessels are poorly developed and disorganized, resulting in some regions that are over-perfused and other areas poorly irrigated ${ }^{45,46}$. In addition, it is well known that the blood flow is aberrant and intermittent in a substantial percentage of vessels ${ }^{47}$. Therefore, tumour cells are likely subjected to an erratic pattern of cyclical hypoxia, as recently revealed by means of oxygen partial pressure $\left(\mathrm{PtO}_{2}\right)$ electrodes in human tumours ${ }^{48}$.

The oscillatory pattern of oxygen availability observed within the tumour awoke the interest in investigating the effects of cyclic hypoxic oscillations on tumour behaviour. These studies have uncovered clear evidence that intermittent hypoxia (IH) can promote tumour malignancy and resistance to conventional therapy ${ }^{49}$. In particular, there are studies showing that a short hypoxic stimulus is sufficient to promote the emergence of spontaneous microscopic metastases $^{50-52}$. Interestingly, cells pre-exposed to cyclic hypoxia, with a frequency pattern similar to that experienced in OSA, increased the metastatic potential in a rodent model $^{52,53}$.

Specifically concerning OSA, there is increasing evidence that IH plays a mechanistic role in the development of well-established cardiovascular, metabolic, and cognitive consequences of OSA through activation of oxidative stress and inflammatory pathways. In fact, IH is one of the most widely studied hallmark features of this sleep breathing disorder. The IH pattern in most animal-based studies aiming to replicate OSA reproduce high frequency hypoxic cycles, low fraction of inspired oxygen $\left(\mathrm{FIO}_{2}\right)$ and the application of the IH challenge during the sleep period ${ }^{54}$. Therefore, the selected IH parameters aim to recapitulate the AHI and oxygen desaturation indices that characterize the moderate and severe OSA patients ${ }^{55}$. These specific conditions manifest pathological outcomes, disabling adaptive processes reported by cyclic hypoxia with a lower frequency oscillation of oxygen tension and with less severe hypoxic levels ${ }^{56}$. Furthermore, in tumours presenting higher metabolic rates, IH may worsen the availability of oxygen in those areas where blood flow is already compromised. Of note, tumour regions that are well perfused will experience oxygen oscillations in blood as a result of the recurrent hypoxemic events applied. Furthermore, tumour cells will also receive the systemic IH-induced molecules released from distant tissues, including reactive oxidative species, proinflammatory cytokines, and angiogenic soluble factors, which can ultimately modulate the 
immune response $\mathrm{e}^{57-61}$. Hypoxia inducible factor-1 (HIF-1) has been widely studied in OSA and cancer as a pivotal molecule in both diseases $^{62-65}$. This transcriptional factor is composed of two subunits, one constitutively expressed and an $\mathrm{O}_{2}$-regulated subunit ${ }^{66}$. Thus, HIF-1 can be induced by hypoxia as a consequence of HIF prolyl-hydroxylase inhibition since it uses oxygen as a co-substrate ${ }^{63,67}$. The HIF induces the expression of a diverse set of genes that assist cells to adapt to hypoxic environments. All these aforementioned considerations make it biologically plausible that $\mathrm{IH}$ mimicking OSA could impose an important challenge in those well-irrigated tumour areas where processes such as cancer invasion and metastasis primarily occur.

\section{Animal Models Linking Obstructive Sleep Apnoea and Cancer}

The complexity of OSA provided the motivation to use animal models of cancer. Such studies facilitate our understanding of how OSA may facilitate cancers to appear, why primary tumours may more likely metastasize, and whether specific preventive interventions and treatments can be used to slow the progression of cancer. Also, the employment of animal models avoids the interaction of most common confounders such as obesity or other metabolic disorders associated to OSA, which are well known to promote cancer progression.

Concerning the IH challenge, very recent exploratory studies mimicking the repetitive oxygen oscillations observed in moderate-to-severe OSA patients have been employed in an increasing number of tumour models. In most of these studies, tumour growth in mice subjected to IH was faster compared to control conditions and the studies have shown increased malignant properties including invasion, metastasis, vascularization, and infiltration of pro-tumoural cells (Fig. 1). In particular, IH promotes more adverse outcomes in all three types of cancer investigated to date, namely melanoma ${ }^{68-71}$, lung adenocarcinoma ${ }^{72,73}$, and kidney cancer $^{74}$ (Table 2). Also, a very recent study has shown that IH not only increases tumour malignancy, but also promotes spontaneous cancer incidence in aged wild-type mice ${ }^{75}$. Indeed, outbreed mice (Swiss CD1) were subjected to IH ( 8 hours/day; 3 months) applied from age 15 to 18 months, equivalent to a human age of 50-60 years. The authors employed two severity paradigms of IH: $80 \mathrm{~s}$ air/40 s $12 \%$ oxygen $(n=49)$, or $7.5 \%$ oxigen $(\mathrm{n}=53)$. Tumoural masses were found in $36.4 \%$ of control mice (8 liver, 7 lung, 5 skin), in $38.8 \%$ in those mice exposed to mild $\mathrm{IH}$ (12\% oxygen) (11 liver, 7 lung, 1 skin) and in $63.5 \%$ in mice exposed to severe $\mathrm{IH}(7.5 \%$ oxygen; $\mathrm{p}=0.005$ vs. control) (11 liver, 15 lung, 7 skin). On the other hand, a previously well-established mouse model of sleep fragmentation reproducing OSA was used to assess the potential role of sleep fragmentation on tumour behaviour ${ }^{76}$. Hakim et al. imposed sleep fragmentation on two syngeneic murine models involving lung epithelial tumour models (TC1 and LLC) and found a twofold tumour growth when compared with normal sleep control conditions. Also, sleep fragmentation-induced tumours showed increased invasion and infiltration toward the surrounding tissues ${ }^{77}$. Zheng et al. ${ }^{78}$ showed similar results and they found the transgenic ablation of nitric oxidase 2 (Nox2) resulted in enhanced oncogenic properties. These 
TABle 2. Summary of the available experimental studies on the effects of intermittent hypoxia and sleep fragmentation mimicking obstructive sleep apnoea in cancer incidence and aggressiveness. This table indicates whether intermittent hypoxia or sleep fragmentation increased tumour proliferation, invasion, metastasis and/or vascularization. All studies were carried out in mice

\begin{tabular}{|c|c|c|c|c|c|c|}
\hline References & Cancer type & $\begin{array}{l}\text { Tumour size/ } \\
\text { proliferation }\end{array}$ & Invasion & Metastasis & Vascularity & Main findings \\
\hline $\begin{array}{l}\text { Almendros et al. } \\
2012^{68}\end{array}$ & $\begin{array}{r}\text { Melanoma } \\
(\text { B16F10) }\end{array}$ & Yes & - & - & - & IH accelerates tumour growth \\
\hline $\begin{array}{l}\text { Almendros et al. } \\
2012^{70}\end{array}$ & $\begin{array}{r}\text { Melanoma } \\
(\text { B16F10) }\end{array}$ & Yes & - & - & Yes & $\begin{array}{l}\text { IH and obesity have no synergistic } \\
\text { effect on tumour growth }\end{array}$ \\
\hline $\begin{array}{l}\text { Almendros et al. } \\
2013^{69}\end{array}$ & $\begin{array}{l}\text { Melanoma } \\
\text { (B16F10) }\end{array}$ & Yes & - & Yes & - & $\begin{array}{l}\text { Cancer mortality and metastasis are } \\
\text { increased under IH conditions }\end{array}$ \\
\hline Eubank et al. $2013^{82}$ & $\begin{array}{r}\text { Melanoma } \\
\text { (B16F10) }\end{array}$ & No & - & Yes & - & $\begin{array}{l}\text { Application of IH increases tumour } \\
\text { spread }\end{array}$ \\
\hline Perini et al. $2016^{71}$ & $\begin{array}{r}\text { Melanoma } \\
(\text { B16F10) }\end{array}$ & Yes & - & - & - & $\begin{array}{l}\text { Melanoma malignant molecules } \\
\text { increased under IH }\end{array}$ \\
\hline $\begin{array}{l}\text { Almendros et al. } \\
2014^{72}\end{array}$ & $\begin{array}{l}\text { Lung carcinoma } \\
\text { (TC1) }\end{array}$ & Yes & Yes & - & - & $\begin{array}{l}\text { IH promoted a shift toward a } \\
\text { pro-tumoural phenotype in } \\
\text { tumour-associated macrophages }\end{array}$ \\
\hline Hakim et al. $2014^{77}$ & $\begin{array}{l}\text { Lung carcinoma } \\
\text { (TC1) }\end{array}$ & Yes & Yes & - & - & $\begin{array}{l}\text { Sleep fragmentation increased } \\
\text { tumour growth through changes in } \\
\text { the host immune response }\end{array}$ \\
\hline Cortese et al. $2015^{73}$ & $\begin{array}{l}\text { Lung carcinoma } \\
\text { (TC1) }\end{array}$ & Yes & Yes & - & - & $\begin{array}{l}\text { The exposure to IH increases the } \\
\text { shedding of cirDNA into circulation } \\
\text { carrying specific epigenetic } \\
\text { modifications }\end{array}$ \\
\hline Zheng et al. $2015^{78}$ & $\begin{array}{l}\text { Lung carcinoma } \\
\text { (TC1) }\end{array}$ & Yes & Yes & - & - & $\begin{array}{l}\text { Perturbed sleep could adversely } \\
\text { affect innate immunity within the } \\
\text { tumour by altering NOX2 expression } \\
\text { and activity }\end{array}$ \\
\hline $\begin{array}{l}\text { Almendros et al. } \\
2015^{83}\end{array}$ & $\begin{array}{l}\text { Lung carcinoma } \\
\text { (TC1) }\end{array}$ & Yes & Yes & - & - & $\begin{array}{l}\text { IH-inflamed adipose tissue is a } \\
\text { potential source of immune cells to } \\
\text { the tumour }\end{array}$ \\
\hline $\begin{array}{l}\text { Gallego-Martín } \\
\text { et al. } 2015^{75}\end{array}$ & - & - & - & - & - & $\begin{array}{l}\text { Incidence of cancer is augmented in } \\
\text { aged mice exposed to } \mathrm{IH}\end{array}$ \\
\hline Vilaseca et al. $2016^{74}$ & $\begin{array}{l}\text { Kidney cancer } \\
\text { (RENCA) }\end{array}$ & No & - & - & Yes & $\begin{array}{l}\text { IH promotes angiogenesis in renal } \\
\text { tumours }\end{array}$ \\
\hline
\end{tabular}

B16F10: mouse melanoma cancer cell line (american type culture collection, ATCC); IH: intermittent hypoxia; NOX: nitric oxidase; RENCA: renal adenocarcinoma (ATCC); TC1: lung carcinoma cell cancer line (ATCC).

findings demonstrated for the first time that the type of sleep disruption experienced by OSA patients enhances tumour aggressiveness in absence of hypoxia. The potential mechanisms involved in $\mathrm{IH}$ - and sleep fragmentation (SF)-induced tumour malignancy have been also studied in further translational studies as outlined below.

\section{Immune Changes Induced by Intermittent Hypoxia and Sleep Fragmentation}

The tumour microenvironment is composed by multiple cell types such as cancer cells, endothelial cells, fibroblasts, and immune cells. These cells are heterogeneous, and 


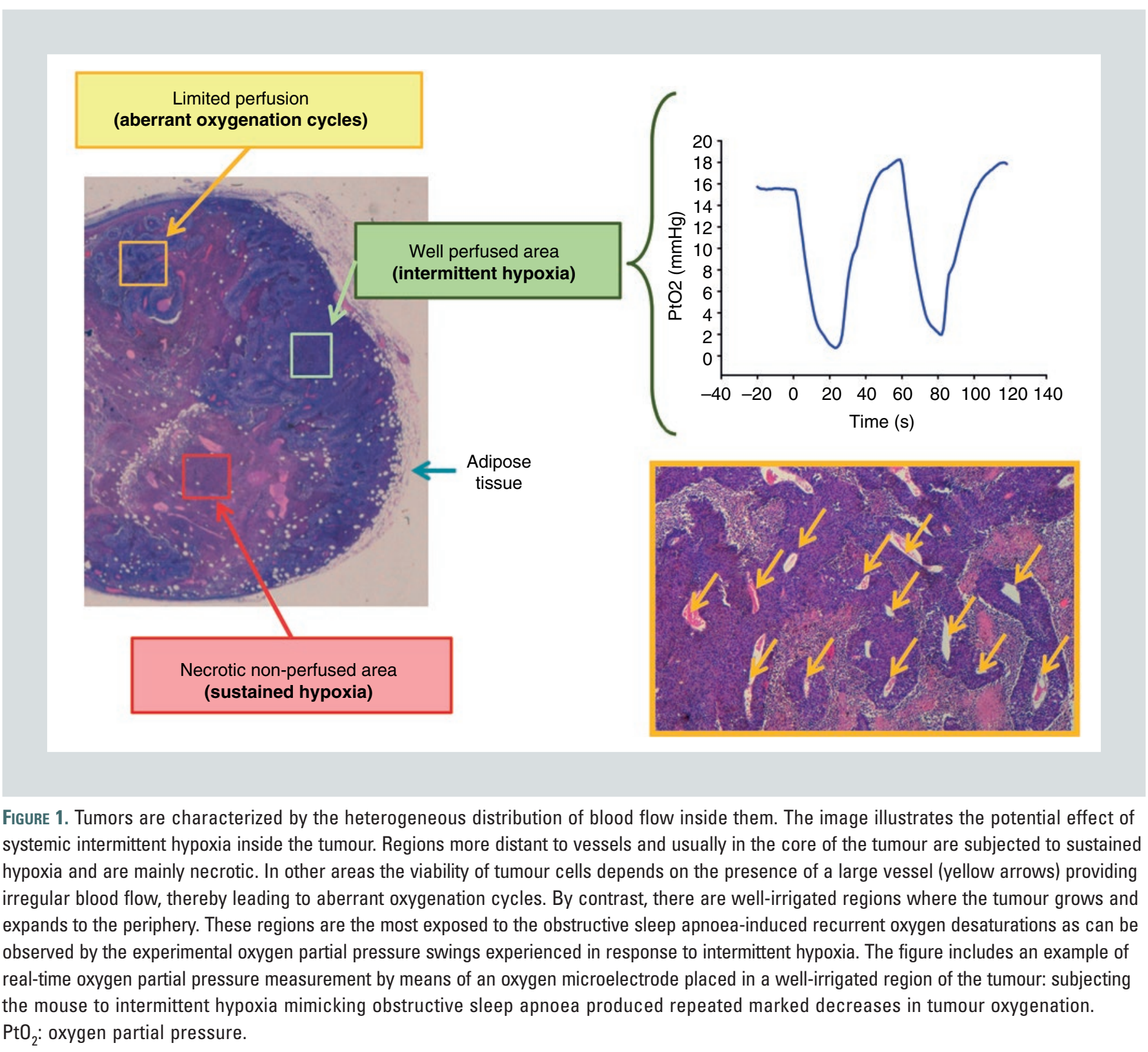

based on patterns of gene expression and function, they have been commonly classified as classically (M1) or alternatively (M2) activated $^{79}$. In terms of cancer, macrophages designated as tumour-associated macrophages (TAM) also present these two phenotypes and constitute the most abundant fraction of leukocytes in the tumour stroma. The presence of certain molecules in the tumour microenvironment facilitates TAM re-education from M1 phenotype (anti-tumour properties) towards M2 (pro-tumoral phenotype), which is known to release factors promoting tumour growth and aggressiveness. The hypoxic microenvironment characteristic of solid tumours has been proposed as a determinant factor in the recruitment of TAMs and their re-education towards the alternative activated $\mathrm{M} 2$ form $^{80}$. Indeed, the changes induced by hypoxia on the phenotypic characteristics 


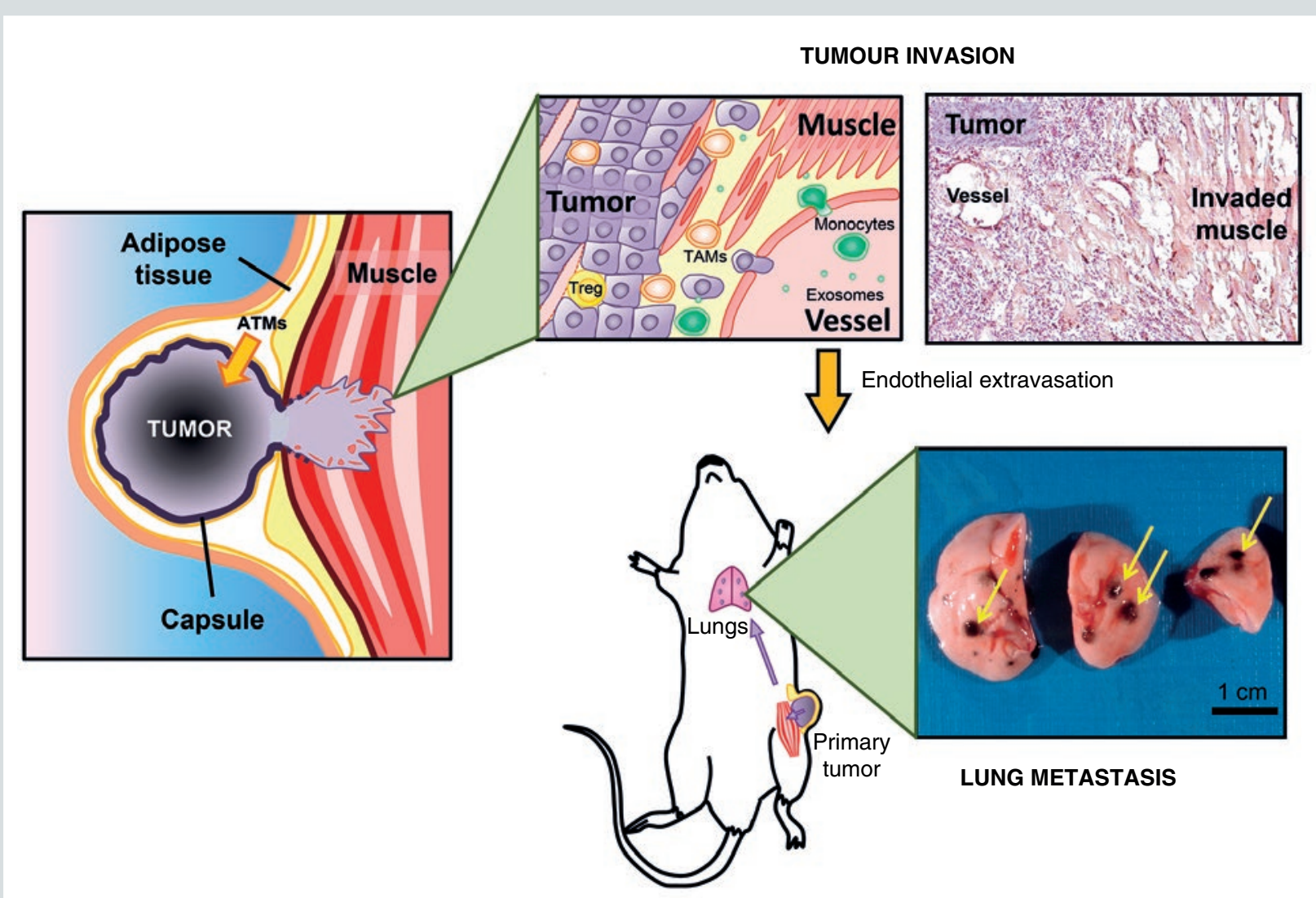

Figure 2. Scheme of main mechanisms described in response to intermittent hypoxia and sleep fragmentation. At short term, both entities promote tumour growth and invasiveness toward surrounding tissues. It has been described that inflamed ipsilateral adipose tissue is a depot of pro-tumoural resident macrophages and other immune suppressor cells such as regulatory T-cells. Monocytes from bone marrow are also recruited within the tumour and exosomes promote endothelial disruption. Exosomes and tumourassociated macrophages have been proposed as mediators of the increased lung melanoma metastasis (yellow arrows) reported at long term.

ATM: adipose tissue macrophage; TAM: tumour-associated macrophage; Treg: regulatory T-cell.

of TAMs include the secretion of mitogenic factors, pro-angiogenic cytokines, and immunosuppressive agents ${ }^{40,81}$.

Recent studies have shown that IH and SF can accelerate the re-education of TAMs toward M2 phenotype ${ }^{77}$. Concretely, SF increased the infiltration of TAMs in the periphery of the tumour and accelerated their polarization toward $\mathrm{M} 2{ }^{77}$. Hakim et al. also assessed metalloproteinase-9 (MMP-9) protein levels, a typical marker of extracellular matrix degradation, in the tumour periphery, revealing an increased activity under sleep fragmentation condition. Of note, TAMs from SF-exposed mice showed higher expression of toll-like receptor-4, which seems to mediate the enhanced tumour progression.

Furthermore, experiments carried out applying IH in mice showed that, similarly to sleep fragmentation, TAMs experience an accelerated 
shift toward M2 phenotype. Assessment of their phenotype correlated with the higher proliferation, migration, invasiveness, and capacity to disrupt the endothelial monolayer of naive tumour cells exposed to TAMs isolated from those mice ${ }^{72}$. In a similar approach, Eubank et al. ${ }^{82}$ observed an increase in expression of MMP7 and a decrease in MMP9 and MMP12 in murine melanoma. These authors suggested that the observed metastatic capacity induced by $\mathrm{IH}$ depends on the specific regulation of MMPs.

In a subsequent study, Almendros et al. ${ }^{83}$ studied the potential source of macrophages to the tumour. In absence of tumour, resident macrophages in the adipose tissue (AT) of mice exposed to IH manifest increased M1 polarization $^{84}$. These findings, in contrast with the increased M2 polarity of TAMs in tumours exposed to IH, suggest that the tumour microenvironment is needed to reverse the classical M1 activation of AT macrophages (ATM) induced by IH. However, when AT is subjected to the tumour microenvironment, $\mathrm{IH}$ operates to recruit such cells and also seems to modulate tumour-AT interactions, enhancing the re-education toward M2 phenotype, resulting in enhanced migration of resident ATMs and bone marrow-derived monocytes to the tumour, thereby enhancing tumour malignancy (Fig. 2).

In addition to TAMs, the presence of other potent immune suppressor cells, such as regulatory $\mathrm{T}$-cells $\left(\mathrm{T}_{\mathrm{reg}}\right)$ and adipose stem cells appear to be mobilized by hypoxic areas which can generate a complex constellation of interactions ${ }^{85-88}$. Also, preliminary data carried out from mice exposed to $\mathrm{IH}$ during six weeks showed that circulating exosomes released under IH conditions are able to increase the migratory capacity ( $46 \%$ ) and invasion ( 2.1-fold) of tumour cells when compared to exosomes obtained from normoxic mice ${ }^{89}$. Similarly, exosomes derived from mice exposed to SF increased tumour cell proliferation $(\sim 13 \%)$, migration $(\sim 2.3$-fold $)$, and extravasation $(\sim 10 \%)$ when compared to exosomes from normal sleep exposed mice ${ }^{90}$.

\section{CONCLUSIONS}

There are increasing epidemiological and clinical studies that strongly suggest a potential relationship between OSA and cancer. However, most of the current human studies to date, with some exceptions, have important limitations since the available databases were not initially designed to study cancer. In parallel to human studies, a considerable number of mechanistic studies carried out in mice have appeared in the last years. However, there are deficits in the knowledge on the vast array of pathways involved in oncogenic processes, which in most cases are similar to responses triggered by $\mathrm{IH}$ and SF. Current translational research using OSA models from different laboratories and carried out in vivo and in vitro suggest that IH and SF may independently increase tumour progression. At a clinical level, it is expected that new studies will focus on specific types of cancer, prospectively and with well-controlled potential carcinogenic confounders. At both a basic and translational level it is necessary to better understand the role played by the mechanisms involved as well as the potential synergistic effect of SF, IH, and hypercapnia in specific types of cancer. 


\section{ACKNOWLEDGEMENTS}

\section{This work was supported in part by the Spanish Ministry of Economy and Competitiveness (Instituto de Salud Carlos III; PI14-00004; PI14/00416) and SEPAR (086/2014).}

\section{REFERENCES}

1. Punjabi NM. The epidemiology of adult obstructive sleep apnea. Proc Am Thorac Soc. 2008;5:136-43.

2. Nieto FJ, Peppard PE, Young T, Finn L, Hla KM, Farre R. Sleep-disordered breathing and cancer mortality: results from the Wisconsin Sleep Cohort Study. Am J Respir Crit Care Med. 2012;186:190-4.

3. Marshall NS, Wong KK, Cullen SR, Knuiman MW, Grunstein RR. Sleep apnea and 20-year follow-up for all-cause mortality, stroke, and cancer incidence and mortality in the Busselton Health Study cohort. J Clin Sleep Med. 2014;10:355-62.

4. Christensen AS, Clark A, Salo P et al. Symptoms of sleep disordered breathing and risk of cancer: a prospective cohort study. Sleep. 2013;36:1429-35.

5. Cohen JM, Li YT, Wu S, Han J, Qureshi AA, Cho E. Sleep duration and sleep-disordered breathing and the risk of melanoma among US women and men. Int J Dermatol. 2015;54:e492-5.

6. Chang WP, Liu ME, Chang WC et al. Sleep apnea and the subsequent risk of breast cancer in women: a nationwide population-based cohort study. Sleep Med. 2014;15:1016-20.

7. Chen JC, Hwang JH. Sleep apnea increased incidence of primary central nervous system cancers: a nationwide cohort study. Sleep Med. 2014;15:749-54.

8. Fang HF, Miao NF, Chen CD, Sithole T, Chung MH. Risk of cancer in patients with insomnia, parasomnia, and obstructive sleep apnea: A nationwide nested case-control study. J Cancer. 2015;6:1140-7.

9. Campos-Rodriguez F, Martinez-Garcia MA, Martinez M et al. Association between obstructive sleep apnea and cancer incidence in a large multicenter Spanish cohort. Am J Respir Crit Care Med. 2013;187:99-105.

10. Martinez-Garcia MA, Campos-Rodriguez F, Duran-Cantolla J et al. Obstructive sleep apnea is associated with cancer mortality in younger patients. Sleep Med. 2014;15:742-8

11. Kendzerska T, Leung RS, Hawker G, Tomlinson G, Gershon AS. Obstructive sleep apnea and the prevalence and incidence of cancer. CMAJ. 2014;186:985-92.

12. Martinez-Garcia MA, Martorell-Calatayud A, Nagore E et al. Association between sleep disordered breathing and aggressiveness markers of malignant cutaneous melanoma. Eur Respir J. 2014;43:1661-8.

13. Vilaseca A, Nguyen DP, Vertosick EA et al. Obstructive sleep apnea and Fuhrman grade in patients with clear cell renal cell carcinoma treated surgically. World J Urol. 2016. [Epub ahead of print].

14. Gharib SA, Seiger AN, Hayes AL, Mehra R, Patel SR. Treatment of obstructive sleep apnea alters transcriptional signatures in circulating leukocytes. Sleep. 2014;37:709-14

15. Gaoatswe G, Kent BD, Corrigan MA et al. Invariant natural killer T cell deficiency and functional impairment in sleep apnea: Links to cancer comorbidity. Sleep. 2015;38:1629-34.

16. Brennan PJ, Brigl M, Brenner MB. Invariant natural killer T cells: an innate activation scheme linked to diverse effector functions. Nat Rev Immunol. 2013;13:101-17.

17. Verkasalo PK, Lillberg K, Stevens RG et al. Sleep duration and breast cancer: a prospective cohort study. Cancer Res. 2005;65:9595-600.

18. Pinheiro SP, Schernhammer ES, Tworoger SS, Michels KB. A prospective study on habitual duration of sleep and incidence of breast cancer in a large cohort of women. Cancer Res. 2006;66:5521-5.
19. McElroy JA, Newcomb PA, Titus-Ernstoff L, Trentham-Dietz A, Hampton JM, Egan KM. Duration of sleep and breast cancer risk in a large population-based case-control study. J Sleep Res. 2006;15:241-9.

20. Kakizaki M, Kuriyama S, Sone T et al. Sleep duration and the risk of breast cancer: the Ohsaki Cohort Study. Br J Cancer. 2008;99:1502-5.

21. Kakizaki M, Inoue $K$, Kuriyama $S$ et al. Sleep duration and the risk of prostate cancer: the Ohsaki Cohort Study. Br J Cancer. 2008;99:176-8.

22. Vogtmann E, Levitan EB, Hale L et al. association between sleep and breast cancer incidence among postmenopausal women in the Women's Health Initiative. Sleep. 2013;36:1437-44.

23. Jiao L, Duan Z, Sangi-Haghpeykar H, Hale L, White DL, El-Serag HB. Sleep duration and incidence of colorectal cancer in postmenopausal women. B J Cancer. 2013;108:213-21.

24. Zhang X, Giovannucci EL, Wu K et al. Associations of self-reported sleep duration and snoring with colorectal cancer risk in men and women. Sleep 2013;36:681-8.

25. Patel SR, Ayas NT, Malhotra MR et al. A prospective study of sleep duration and mortality risk in women. Sleep. 2004;27:440-4.

26. Kripke DF, Garfinkel L, Wingard DL, Klauber MR, Marler MR. Mortality associated with sleep duration and insomnia. Arch Gen Psychiatry. 2002;59:131-6.

27. Kripke DF, Langer RD, Elliott JA, Klauber MR, Rex KM. Mortality related to actigraphic long and short sleep. Sleep Med. 2011;12:28-33.

28. Gallicchio L, Kalesan B. Sleep duration and mortality: a systematic review and meta-analysis. J Sleep Res. 2009;18:148-58.

29. Ikehara S, Iso H, Date $C$ et al. Association of sleep duration with mortality from cardiovascular disease and other causes for Japanese men and women: the JACC study. Sleep. 2009;32:295-301.

30. Thompson CL, Larkin EK, Patel S, Berger NA, Redline S, Li L. Short duration of sleep increases risk of colorectal adenoma. Cancer. 2011;117:841-7.

31. Truong T, Liquet B, Menegaux F et al. Breast cancer risk, nightwork, and circadian clock gene polymorphisms. Endocr Relat Cancer. 2014;21:629-38.

32. Gapstur SM, Diver WR, Stevens VL, Carter BD, Teras LR, Jacobs EJ. Work schedule, sleep duration, insomnia, and risk of fatal prostate cancer. Am Prev Med. 2014;46(Suppl 1):S26-33.

33. Stevens RG, Brainard GC, Blask DE, Lockley SW, Motta ME. Breast cancer and circadian disruption from electric lighting in the modern world. CA Cancer J Clin. 2014;64:207-18.

34. Schernhammer ES, Laden F, Speizer FE et al. Night-shift work and risk of colorectal cancer in the nurses' health study. J Natl Cancer Inst. 2003; $95: 825-8$.

35. Schernhammer ES, Kroenke CH, Laden F, Hankinson SE. Night work and risk of breast cancer. Epidemiology. 2006;17:108-11.

36. Akerstedt T, Knutsson A, Narusyte J, Svedberg P, Kecklund G, Alexanderson K. Night work and breast cancer in women: a Swedish cohort study. BMJ Open. 2015;5:e008127.

37. Viswanathan AN, Hankinson SE, Schernhammer ES. Night shift work and the risk of endometrial cancer. Cancer Res. 2007;67:10618-22.

38. Hansen J. Risk of breast cancer after night- and shift work: current evidence and ongoing studies in Denmark. Cancer Causes Control. 2006;17:531-7.

39. Liu Y, Song X, Wang X et al. Effect of chronic intermittent hypoxia on biological behavior and hypoxia-associated gene expression in lung cancer cells. J Cell Biochem. 2010;111:554-63.

40. Lewis C, Murdoch C. Macrophage responses to hypoxia: implications for tumor progression and anti-cancer therapies. Am J Pathol. 2005;167:627-35.

41. Semenza GL. Hypoxia-inducible factors: mediators of cancer progression and targets for cancer therapy. Trends Pharmacol Sci. 2012;33:207-14.

42. Rofstad EK, Galappathi K, Mathiesen B, Ruud EB. Fluctuating and diffusion-limited hypoxia in hypoxia-induced metastasis. Clin Cancer Res. 2007;13:1971-8.

43. Semenza GL, Wang GL. A nuclear factor induced by hypoxia via de novo protein synthesis binds to the human erythropoietin gene enhancer at a site required for transcriptional activation. Mol Cell Biol. 1992;12:5447-54.

44. Semenza GL. Targeting HIF-1 for cancer therapy. Nat Rev Cancer. 2003; 3:721-32. 
45. Kimura H, Braun RD, Ong ET et al. Fluctuations in red cell flux in tumor microvessels can lead to transient hypoxia and reoxygenation in tumor parenchyma. Cancer Res. 1996;56:5522-8.

46. Dewhirst MW, Kimura H, Rehmus SW et al. Microvascular studies on the origins of perfusion-limited hypoxia. Br J Cancer Suppl. 1996;27:S247-51.

47. Brurberg KG, Benjaminsen IC, Dorum LM, Rofstad EK. Fluctuations in tumor blood perfusion assessed by dynamic contrast-enhanced MRI. Magn Reson Med. 2007;58:473-81.

48. Matsumoto S, Yasui H, Mitchell JB, Krishna MC. Imaging cycling tumor hypoxia. Cancer Res. 2010;70:10019-23.

49. Dewhirst MW, Cao Y, Moeller B. Cycling hypoxia and free radicals regulate angiogenesis and radiotherapy response. Nat Rev Cancer. 2008;8:425-37.

50. Toffoli S, Michiels C. Intermittent hypoxia is a key regulator of cancer cell and endothelial cell interplay in tumours. FEBS J. 2008;275:2991-3002.

51. Cairns RA, Kalliomaki T, Hill RP. Acute (cyclic) hypoxia enhances spontaneous metastasis of KHT murine tumors. Cancer Res. 2001;61:8903-8.

52. Rofstad EK, Gaustad JV, Egeland TA, Mathiesen B, Galappathi K. Tumors exposed to acute cyclic hypoxic stress show enhanced angiogenesis, perfusion and metastatic dissemination. Int J Cancer. 2010;127:1535-46.

53. Martinive P, Defresne F, Bouzin C et al. Preconditioning of the tumor vasculature and tumor cells by intermittent hypoxia: implications for anticancer therapies. Cancer Res. 2006;66:11736-44.

54. Quintero M, Gonzalez-Martin MC, Vega-Agapito V et al. The effects of intermittent hypoxia on redox status, NF-kappaB activation, and plasma lipid levels are dependent on the lowest oxygen saturation. Free Radic Biol Med. 2013;65:1143-54.

55. Ruehland WR, Rochford PD, O'Donoghue FJ, Pierce RJ, Singh P, Thornton AT. The new AASM criteria for scoring hypopneas: impact on the apnea hypopnea index. Sleep. 2009;32:150-7.

56. Almendros I, Wang Y, Gozal D. The polymorphic and contradictory aspects of intermittent hypoxia. Am J Physiol Lung Cell Mol Physiol. 2014;307:L129-40.

57. Lavie L. Intermittent hypoxia: the culprit of oxidative stress, vascular inflammation and dyslipidemia in obstructive sleep apnea. Expert Rev Respir Med. 2008;2:75-84.

58. Gozal D, Kheirandish-Gozal L, Bhattacharjee R, Kim J. C-reactive protein and obstructive sleep apnea syndrome in children. Front Biosci (Elite Ed). 2012;4:2410-22

59. Gozal D, Lipton AJ, Jones KL. Circulating vascular endothelial growth factor levels in patients with obstructive sleep apnea. Sleep. 2002;25:59-65.

60. Lurie A. Inflammation, oxidative stress, and procoagulant and thrombotic activity in adults with obstructive sleep apnea. Adv Cardiol. 2011;46:43-66.

61. Lin QC, Chen LD, Yu YH, Liu KX, Gao SY. Obstructive sleep apnea syndrome is associated with metabolic syndrome and inflammation. Eur Arch Otorhinolaryngol. 2014;271:825-31.

62. Semenza GL, Prabhakar NR. HIF-1-dependent respiratory, cardiovascular, and redox responses to chronic intermittent hypoxia. Antioxid Redox Signal. 2007;9:1391-6.

63. Yuan G, Nanduri J, Khan S, Semenza GL, Prabhakar NR. Induction of HIF-1alpha expression by intermittent hypoxia: involvement of NADPH oxidase, Ca2+ signaling, prolyl hydroxylases, and mTOR. J Cell Physiol. 2008;217:674-85.

64. Peng YJ, Yuan G, Ramakrishnan D et al. Heterozygous HIF-1alpha deficiency impairs carotid body-mediated systemic responses and reactive oxygen species generation in mice exposed to intermittent hypoxia. J Physiol. 2006;577:705-16.

65. Semenza GL. HIF-1 mediates metabolic responses to intratumoral hypoxia and oncogenic mutations. J Clin Invest. 2013;123:3664-71.

66. Wang GL, Jiang BH, Rue EA, Semenza GL. Hypoxia-inducible factor 1 is a basic-helix-loop-helix-PAS heterodimer regulated by cellular O2 tension. Proc Natl Acad Sci USA. 1995;92:5510-14.

67. Coleman ML, Ratcliffe PJ. Oxygen sensing and hypoxia-induced responses. Essays Biochem. 2007;43:1-15.

68. Almendros I, Montserrat JM, Ramirez J et al. Intermittent hypoxia enhances cancer progression in a mouse model of sleep apnoea. Eur Respir J. 2012;39:215-17.
69. Almendros I, Montserrat JM, Torres M et al. Intermittent hypoxia increases melanoma metastasis to the lung in a mouse model of sleep apnea. Respir Physiol Neurobiol. 2013;186:303-7.

70. Almendros I, Montserrat JM, Torres $\mathrm{M}$ et al. Obesity and intermittent hypoxia increase tumor growth in a mouse model of sleep apnea. Sleep Med. 2012;13:1254-60.

71. Perini S, Martinez D, Montanari CC, Fiori CZ. Enhanced expression of melanoma progression markers in mouse model of sleep apnea. Rev Port Pneumol (2006) 2016. [Epub ahead of print].

72. Almendros I, Wang Y, Becker L et al. Intermittent hypoxia-induced changes in tumor-associated macrophages and tumor malignancy in a mouse model of sleep apnea. Am J Respir Crit Care Med. 2014;189:593-601.

73. Cortese R, Almendros I, Wang Y, Gozal D. Tumor circulating DNA profiling in xenografted mice exposed to intermittent hypoxia. Oncotarget. 2015;6:556-69.

74. Vilaseca A, Musquera M, Torres M et al. Intermittent hypoxia increases tumo angiogenesis in a mouse model of kidney cancer. Eur Urol. 2016;15:E218.

75. Gallego-Martin T, Obeso A, Yubero S et al. Effects of long term intermittent hypoxia (IH) mimicking obstructive sleep apnea (OSA) on spontaneous tumorigenesis in aged mice. Eur Respir J. 2016;46(Suppl 59):OA293.

76. Ramesh V, Nair D, Zhang SX et al. Disrupted sleep without sleep curtailment induces sleepiness and cognitive dysfunction via the tumor necrosis factor-alpha pathway. J Neuroinflammation. 2012;9:91.

77. Hakim F, Wang Y, Zhang SX et al. Fragmented sleep accelerates tumor growth and progression through recruitment of tumor-associated macrophages and TLR4 signaling. Cancer Res. 2014;74:1329-37.

78. Zheng J, Almendros I, Wang Y et al. Reduced NADPH oxidase type 2 activity mediates sleep fragmentation-induced effects on TC1 tumors in mice. Oncoimmunology. 2015;4:e976057.

79. Gordon S, Taylor PR. Monocyte and macrophage heterogeneity. Nat Rev Immunol. 2005;5:953-64.

80. Tripathi C, Tewari BN, Kanchan RK et al. Macrophages are recruited to hypoxic tumor areas and acquire a pro-angiogenic M2-polarized phenotype via hypoxic cancer cell derived cytokines Oncostatin M and Eotaxin. Oncotarget. 2014;5:5350-68.

81. Obeid E, Nanda R, Fu YX, Olopade OI. The role of tumor-associated macrophages in breast cancer progression (review). Int J Oncol. 2013;43:5-12.

82. Eubank T, Sherwani S, Peters S, Gross A, Evans R, Magalang UJ. Intermittent hypoxia augments melanoma tumor metastases in a mouse model of sleep apnea. Am J Respir Crit Care Med. 2013;187:A2302.

83. Almendros I, Gileles-Hillel A, Khalyfa A et al. Adipose tissue macrophage polarization by intermittent hypoxia in a mouse model of OSA: effect of tumor microenvironment. Cancer Lett. 2015;361:233-9.

84. Carreras A, Zhang SX, Almendros I et al. Resveratrol attenuates intermit tent hypoxia-induced macrophage migration to visceral white adipose tissue and insulin resistance in male mice. Endocrinology. 2015;156:437-43.

85. Murdoch C, Giannoudis A, Lewis CE. Mechanisms regulating the recruit ment of macrophages into hypoxic areas of tumors and other ischemic tissues. Blood. 2004;104:2224-34.

86. Riboldi E, Porta C, Morlacchi S, Viola A, Mantovani A, Sica A. Hypoxia-mediated regulation of macrophage functions in pathophysiology. Int Immunol. 2013;25:67-75

87. Zhao BC, Zhao B, Han JG, Ma HC, Wang ZJ. Adipose-derived stem cells promote gastric cancer cell growth, migration and invasion through SDF-1/ CXCR4 axis. Hepatogastroenterology. 2010;57:1382-9.

88. Jotzu C, Alt E, Welte G et al. Adipose tissue derived stem cells differentiate into carcinoma-associated fibroblast-like cells under the influence of tumor derived factors. Cell Oncol (Dordr). 2011;34:55-67.

89. Almendros I, Khalyfa A, Gileles-Hillel A, Farre R, Gozal D. Tumor cell malignant properties are enhanced by circulating exosomes in a mouse model of intermittent hypoxia mimicking sleep apnea. Am J Respir Crit Care Med. 2015;191:A5154.

90. Khalyfa A, Almendros I, Gileles-Hillel A, Gozal D. Exosomes released into the circulation under chronic sleep fragmentation potentiate tumor malignancy in a mouse model of sleep apnea. Am J Respir Crit Care Med. 2015;191:A2693. 